American Journal of Applied Sciences 8 (2): 156-163, 2011

ISSN 1546-9239

(C) 2010 Science Publications

\title{
The Effect of the International Accounting Standards on the Related Party Transactions Disclosure
}

\author{
${ }^{1}$ Stauropoulos Antonios, ${ }^{1}$ Samaras Ioannis and ${ }^{2}$ Arsenos Panagiotis \\ ${ }^{1}$ Department of Applied Informatics, University of Macedonia, \\ 156 Egnatia Str, P.O Box 1591540 06, Thessaloniki Greece \\ ${ }^{2}$ Department of Business Administration, TEI of Ionian Islands
}

\begin{abstract}
Problem statement: Several recent North American corporate scandals have brought attention to the potential for accounting manipulations associated with Related Party Transactions (RPTs), which have lead to a decline in perceived earnings quality. We examine the value relevance of disclosed RPTs in Greek corporations. Approach: We focus on two types of RPTs: sales of goods and sales of assets, using a value relevance approach. Results: From 2002-2007, we find that the reported earnings of firms selling goods or assets to related parties exhibit a lower valuation coefficient than those of firms in Greece without such transactions. This result is not observed during 2005-2007 after a new fair value measurement rule for RPTs came into effect. Conclusion: Our evidence suggests that the new RPT regulation in Greece is perceived to be effective at reducing the potential misuse of RPTs for earnings management purposes. Since RPTs have been the subject of numerous scandals in North America, our evidence from the Greek stock markets suggests that new RPT accounting standards could prove an efficient solution to this issue.
\end{abstract}

Key words: International Financial Reporting Standards (IFRS), value relevance, Related Party Transactions (RPTs), hypotheses development, GAAP, International Accounting Standards Board (IASB), earnings management, Return-On-Assets (ROA), Earnings Per Share (EPS)

\section{INTRODUCTION}

In this study we examine value relevance regarding the disclosures of related party transactions made by firms listed in Athens Stock Exchange before and after the adoption of International Financial Reporting Standards (IFRS).

Many Greek listed companies are members of state-owned companies. Other companies are members of business collaborations. Most of the existing related party transactions are an outcome of capital investment process or mergers and acquisitions. The usefulness of the related party transactions within (inside) these corporations is the allocation of the internal resources, the minimization of the transaction costs and the improvement of the Return-On-Assets (ROA). In contrast, these dealings, when used opportunistically by managers and stakeholders can lead to deceptive effects and unfavorably harm shareholders' wealth. Worries has been expressed, concerning shareholders control and their manipulation of listed firms as financing vehicles in order to reallocate the capitals of those firms to other ventures. Furthermore, managers might overestimate earnings to gain rights issue permission through wash sales with related parties and also profit from purchasing and selling at excessive prices, or by exchanging assets with various qualities (Ge et al., 2010).

The unification of international financial markets created the necessity for accounting standards and regulations to be globally comparable (Zarzeski, 1996). The mandatory adoption of International Financial Reporting Standards (IFRS) by listed companies of the European Union, as of January 1, 2005, should help investors to take investing decisions (based on common methods) and increase stock markets profitability (Botosan and Plumlee, 2002; Healy and Palepu, 2001; Leuz, 2003, Vazakidis et al, 2010). However, the global verification of IFRS necessitates their high quality (Tendeloo and Vanstraelen, 2005).

Greek listed firms on Athens Stock Exchange adopt IFRS, since it is obligatory for them. On the contrary, not listed firms make use of the Greek GAAP. The financial results of the firms have been affected from the change of Greek GAAP into IFRS (Mandilas et al., 2004, Vazakidis and Athianos, 2010).

Corresponding Author: Ioannis Samaras, Department of Applied Informatics, University of Macedonia, 156 Egnatia str, P.O Box 1591540 06, Thessaloniki Greece Tel: +302310 891862 
The transition had as an outcome the development of an adjustment mechanism, in order firms to avoid any trouble made by the IFRS implementation (Tarca, 2004) and also to the improvement of particular accounting variables, such as efficiency and compensation, aiming at the straightening of the firms' financial position (Weil et al., 2006).

Furthermore, this study investigates if the adoption of IFRS is effective and earnings managements cannot be used opportunistically from related party transactions, there is no need for investors to discount firms' involvement in related party transactions. Moreover, examines whether the earnings management has been reduced due to the IFRS implementation and if the value relevance of accounting numbers based on IFRS has been increased. The examining periods of our study is before and after the IFRS were officially adopted.

In the year of the first adoption, 2005, firms reported lower key accounting volumes, such as liquidity, profitability and growth, reasoning to the fair value measurement of IFRS and the associated variable costs. In the years followed, the financial measures reported were improved and their value relevance was higher (Athianos et al., 2005, Iatridis and Rouvolis, 2010).

In our analysis we firstly investigate whether the information concerning the disclosures of related party transactions are value relevant for investors, before the adoption of IFRS, where fair value measurement does not exist. Secondly, we examine if investors confrontation concerning the reliability of related party transaction information has been changed due to the adoption of the IFRS and the fair value installation.

Literature review: An accounting amount is determined as value relevant if it is associated with the equity market value predictions. Accounting measures are supposed to be value relevant if they have a predicted significant relation with share prices, as long as the amounts represent value relevant information to investors concerning the firm valuation. Accounting numbers are relevant to financial statement users, only if they are able to differentiate the user's decision. There is no need for the information to be new, in order to be useful for the financial statement interested groups. There is a difference among the principles of value relevance and decision relevance (Barth et al., 2001).

Value relevant research is of great interest for a wide number of parties; not only for academics, but also standard setters are interested like the FASB and the International Accounting Standards Board (IASB), policy makers and regulators, managers of the firms and users of the financial statements (Barth et al., 2001).
According to prior research the adaptation of IFRS promotes accounting numbers with comparability and quality, concluding to accounting harmonization, growth of investments and decrease in the cost of capital (Barth et al., 2005). Reduction of earnings management is a consequence of the firms IFRS implementation (Render and Gaeremynck, 2007).

It is questionable the firm's performance with regard to the related party transactions. Finally, it would be of great interest, to investigate if there is an association between the related party transactions and the properties of financial reports or the introduction for earning management incentives (Bushman and Smith, 2001; Gordon and Henry, 2003; Sherman and Young, 2001).

Related party transactions: Kohlbeck and Mayhew (2010) show that, according to their market analysis, significantly lower valuation is obtained by Related Party (RP) firms and non-RP firms report marginally lower subsequent returns. Furthermore, they have stated that related party transactions have the ability for insiders to record firm wealth charging stakeholders. Contrarily, with respect to related party transactions, it can be achieved creative strategic partnership, promoted risk sharing and facilitating contracting.

Kohlbeck and Mayhew (2010) resulted in an existing equilibrium of related party transaction disclosure and lower firm valuation. Moreover, they found that related party firms and their valuations are negatively associated, which recommends differential valuation of firms disclosing related party transactions that is statistically and economically significant. Their study findings obtain that the market evaluates residual income more for non-related party firms than for related party firms. The residual income findings verify that investors place less reliance on reported income and/or discount the return to shareholders from future income.

In reference to international evidence, expropriation of assets (i.e., tunnelling) by controlling parties impairs minority shareholders, which causes a reduction in the stock market values and returns for those firms that have access in such transactions (Johnson, 2000; Jiang et al., 2005; Jiang and Wong, 2010). In addition, stock market research suggestions indicate that laws that demand disclosure of related party transactions are associated with better developed stock markets (Djankov et al., 2008; La Porta et al., 2006). Gordon et al. (2007) stated, that related party transactions are considered as a natural part of the business and a high volume of such transactions is contained in firms without the commitment of accounting and financial fraud. 
The manipulation of accounting accruals will transfer profits for one fiscal year to the next, reported profits of future years will not be affected by this movement. Therefore, the manipulation of the transfer price, that the related party transactions have, is a permanent earning modification. According to Jian and Wong (2008) study, Chinese listed firms use related sales to the controlling owner to sustain earnings. The levels of related sales and operating profits rising from related sales are unusually increased when firms have incentives to manage earnings. Moreover, the discretionary related party accounts receivable is not significantly positive when firms have incentives to meet earnings targets. The high abnormal related sales reported in their study are not an absolute result of abnormal accrued sales, which would produce significantly positive discretionary related accounts receivable; rather, the abnormal related sales can also be cash sales from the listed firms to their controlling owners. In general, prior academic research has focused much more on tunnelling than on propping.

Tunnelling and propping are of particular significance in companies with concentrated ownership. Concentrated ownership structures are very common in many countries around the world and particularly in East Asia (La Porta et al., 1999; Claessens et al., 2000). Controlling shareholders in such firms have the power to expropriate minority shareholders but can also use their private wealth to prop up firms in distress.

There are two relevant streams in prior literature. The first stream has attempted to measure the expropriation of minority shareholders indirectly, using different proxies for the degree of expropriation.

These studies do not examine whether the value of minority shareholdings has declined following specific corporate actions. Some studies use the legal system (in particular investor protection) as a proxy for the likelihood of expropriation (La Porta et al., 1998, 2000b; Johnson, 2000; Djankov et al., 2008). The legal system has been shown to affect dividend policy (La Porta et al., 2000a; 2000b), firm valuation (La Porta et al., 2002) and stock liquidity (Brockman and Chung, 2003). Other studies use the deviation of cash flow from control rights as a proxy for the likelihood of expropriation. This measure has been shown to affect dividend policy (Faccio et al., 2001), firm valuation (Claessens et al., 2002; Lemmon et al., 2003; Baek et al., 2004), firm profitability (Joh, 2003) and the propagation of earnings shocks within the firm (Bertrand et al., 2002). A second stream of literature examines actions of controlling shareholders that may directly impact the firms they control, typically through related party transactions between publicly listed firms and their controlling shareholders. The literature recognizes three motivations behind related party transactionstunnelling, propping and earnings management. The tunnelling literature provides evidence that the value of minority shareholdings has declined as a result of specific related party transactions. Cheung et al. (2006) examine a large set of related party transactions between Hong Kong listed companies and their controlling shareholders. They find that, on average, firms earn significant negative excess returns both at the initial announcement and during the 12-month period following the announcement of connected transactions that are a priori likely to result in expropriation of minority shareholders. In a similar spirit, Baek et al. (2006) examine private securities offerings by Korean industrial groups. La Porta et al. (2003) examine lending by Mexican banks to firms controlled by the bank's owners. They show that related loans carry lower interest rates compared to arm's length loans; they are more likely to default and have lower recovery rates following default.

A few recent studies examine the Chinese market using different proxies for tunnelling than our study. Berkman et al. (2008) examine loan guarantees issued by Chinese firms to their controlling shareholders and show that these transactions are less likely in statecontrolled firms. Gao and Kling (2008) use the difference between accounts receivable and accounts payable to related parties as a proxy for tunnelling and show that this measure is related to corporate governance characteristics.

Evidence on propping is more limited. Friedman et al. (2003) recognize that propping is the flip side of tunnelling but do not provide direct evidence. In their framework, controlling shareholders can choose to tunnel or to prop up their firm (in the latter case hoping that saving a distressed firm may allow them to tunnel more in the future). Bae et al. (2002) find that the value of Korean firms affiliated with industrial group declines when they are asked to bail out under-performing firms in the group through rescue mergers. Cheung et al. (2006) find some limited examples of propping in the Hong Kong market. Finally, Jiang and Wong (2003) show that Chinese firms belonging to business groups use related party transactions with their parents (in particular trading goods and services) as away of manipulating earnings.

\section{MATERIALS AND METHODS}

Sample selection: The basis of this study is composed by annual reports and financial statements obtained from the internet database. The sample consisted by 
companies were included in FTSE-ASE 20 index (ASE). Our observations span from 2002-2007. The examine period divided in the following sub-periods: 2002-2004 and 2005-2007. The partition point is the year 2005 when the adoption of the IAS has been issued. A regression analysis has been performed on the sub-samples for these two test periods.

Most of the companies for the years 2002-2004 had reported their financial statements in the Greek national accounting system, whereas few of them reported in both Greek GAAP and IAS.

In order to determine if the conversion from Greek GAAP to IAS has increased the harmonisation level, it was important the collection of data before as well as after the adoption period. It is a great need for the performance of the statistical test to have pre- and post- adoption years. Making use of the data formed from 2002-2004 (pre-change), we can compare with the practices formed from 2005-2007 (after the adoption of IAS).

Research and hypotheses development: According to Athianos et al. (2007), translating the financial statements from Greek GAAP-IAS has extensive and significant differences in fixed tangible assets, depreciation of fixed tangible assets, valuation of inventories, deferred taxation, foreign currency translation, brand and trademarks and goodwill. Greek GAAP emphasize in the prudence principle and income smoothing, while IASs underline fair-value and balance sheet valuation. Many listed companies, in order to manage their earnings and get rights issue approval, make use of the related party sales.

In reference to Jiang and Wong (2006), companies make use of related sales in order to achieve securities regulators' earnings targets for share issuance and maintaining listing status. Moreover, the examination of related party transactions in the US context indicates the association of related party transactions with earnings management (Gordon and Henry, 2005). Additionally, earnings management can also be used through the sales of assets (Herrmann et al., 2003).

As a result the hypotheses development of this study is as follows:

H1A: In the pre-adoption period of IASs, that allows the manipulation of earnings through related party transactions, the parameter of earnings valuation is lower for firms selling goods to related parties than for firms without such transactions
H10: In the post-adoption period of IASs, that prohibit the manipulation of earnings through related party transactions, there is no differentiation in the earnings valuation of firms selling goods to related parties than for firms without such transactions.

H2A: In the pre-adoption period of IASs, that allows the manipulation of earnings through related party transactions, the parameter of earnings valuation is lower for firms selling assets to related parties than for firms without such transactions.

H20: In the post-adoption period of IASs, that prohibit the manipulation of earnings through related party transactions, there is no differentiation in the earnings valuation of firms selling assets to related parties than for firms without such transactions.

The price levels model is frequently used in the accounting literature to test the value relevance of accounting information. The price levels design is appropriate when the research question is the determination of what accounting numbers are reflected in firm value (Barth et al., 2001; Beaver, 2002; Athianos et al., 2005). It also provides the added benefits of not needing the precise release date of the annual report and does not require that assumption be made about the market expectation model. Therefore, according to Ge et al. (2010) we apply the following regression model to test the above hypotheses:

PRICE $=\beta_{0}+\beta_{1} B V+\beta_{2}$ EPS $+\beta_{3}$ EPS $* S_{\text {goods }}+\beta_{4}$ EPS $* S_{\text {assets }}+\varepsilon$

Where:

PRICE = Stock price per share four months after the year-end

EPS = Annual earnings per share

$\mathrm{BV}=$ Book value of equity per share

$\mathrm{S}_{\text {goods }}=$ Dummy variable, coded 1 for firms selling goods to related parties and 0 otherwise.

$\mathrm{S}_{\text {assets }}=$ Dummy variable, coded 1 for firms selling assets to related parties and 0 otherwise

\section{RESULTS AND DISCUSSION}

In Table 1 we provide descriptive statistics for the sample observations. There are three testing periods, 2002-2004, 2004-2005 and 2005-2007. Book value per share ranges from $0.430-22.610$ for 2002-2004, 0.44022.610 for 2004-2005 and 1.515-22.758 for 2005-2007. 
Am. J. Applied Sci., 8 (2): 156-163, 2011

Table 1: Descriptive statistics

\begin{tabular}{|c|c|c|c|c|c|}
\hline \multirow{2}{*}{$\begin{array}{l}\text { Variables } \\
\text { Testing period 200- } 2004\end{array}$} & Min & \multicolumn{2}{|r|}{ Max } & Mean & SD \\
\hline & & & & & \\
\hline \multicolumn{6}{|l|}{ Test Variables } \\
\hline Book Value (BV) & 0,430 & \multicolumn{2}{|r|}{22,610} & 6,026 & 5,553 \\
\hline Earnings Per Share (EPS) & \multirow[t]{2}{*}{0,070} & \multicolumn{2}{|r|}{2,11} & 0,705 & 0,548 \\
\hline \multicolumn{5}{|l|}{ Testing period 2004-2005 } & \\
\hline \multicolumn{6}{|l|}{ Test variables } \\
\hline Book value (BV) & \multirow{2}{*}{$\begin{array}{l}0,440 \\
0,070\end{array}$} & \multicolumn{2}{|r|}{22,610} & 7,649 & 6,252 \\
\hline Earnings Per Share (EPS) & & \multicolumn{2}{|r|}{5,22} & 1,057 & 1,128 \\
\hline \multicolumn{6}{|l|}{ Testing period 2005-2007 } \\
\hline \multicolumn{6}{|l|}{ Test variables } \\
\hline Book Value (BV) & \multirow{2}{*}{$\begin{array}{l}1,515 \\
0,100\end{array}$} & \multicolumn{2}{|r|}{22,758} & 8,434 & 5,797 \\
\hline Earnings Per Share (EPS) & & \multicolumn{2}{|r|}{5,220} & 1,271 & 0,992 \\
\hline \multicolumn{6}{|l|}{ Table 2: Correlation matrix } \\
\hline Variable & Price & $\mathrm{BV}$ & EPS & EPS $* S_{\text {goods }}$ & EPS $* S_{\text {assets }}$ \\
\hline \multicolumn{6}{|l|}{ Panel A: 2002-2004 data } \\
\hline BV & 1,000 & 0,209 & $0,393^{*}$ & $0,393^{*}$ & $0,377^{*}$ \\
\hline Price & 0,209 & 1,000 & $-0,031$ & $-0,031$ & 0,018 \\
\hline EPS & $0,393^{*}$ & $-0,031$ & 1,000 & $1,000^{* *}$ & $0,959^{* *}$ \\
\hline EPS $* S_{\text {goods }}$ & $0,393^{*}$ & $-0,031$ & $1,000^{* *}$ & 1,000 & $0,962^{* *}$ \\
\hline EPS $* S_{\text {assets }}$ & $0,377^{*}$ & 0,018 & $0,959^{* *}$ & $0,962^{* *}$ & 1,000 \\
\hline \multicolumn{6}{|l|}{ Panel B: 2004-2005 data } \\
\hline BV & 1,000 & 0,242 & 0,204 & 0,204 & 0,208 \\
\hline Prce & 0,242 & 1,000 & 0,318 & 0,318 & 0,312 \\
\hline EPS & 0,204 & 0,318 & 1,000 & $1,000^{* *}$ & $0,980^{* *}$ \\
\hline EPS* $S_{\text {goods }}$ & 0,204 & 0,318 & $1,000^{* *}$ & 1,000 & $0,980^{* *}$ \\
\hline EPS $* S_{\text {assets }}$ & 0,208 & 0,312 & $0,980^{* *}$ & $0,980^{* *}$ & 1,000 \\
\hline \multicolumn{6}{|l|}{ Panel B: 2005- 2007 data } \\
\hline BV & 1,000 & 0,169 & 0,168 & 0,168 & 0,231 \\
\hline Prce & 0,169 & 1,000 & $0,377^{*}$ & $0,377^{*}$ & $0,369^{*}$ \\
\hline EPS & 0,168 & $0,377^{*}$ & 1,000 & $1,000^{* *}$ & $0,942^{* *}$ \\
\hline EPS* $S_{\text {goods }}$ & 0,168 & $0,377^{*}$ & $1,000^{* *}$ & 1,000 & $0,942^{* *}$ \\
\hline EPS* $S_{\text {assets }}$ & 0,231 & $0,369^{*}$ & $0,942^{* *}$ & $0,942^{* *}$ & 1,000 \\
\hline
\end{tabular}

${ }^{*}$ : Significant at the 0.05 level ; ${ }^{* *}$ : Significant at the 0.01 level

In Table 2 we provide the correlation matrices of regression variables. Panel A presents the correlation matrix for the 2002-2004 sub-sample, Panel B contains the correlation matrix for the 2004-2005 sub-sample, finally, Panel C tabulates correlations matrix for 20052007. Some of the explanatory variables are significantly correlated with each other, but the magnitudes of the correlation coefficients are modest.

However, EPS, EPS*S $\mathrm{S}_{\text {goods }}$ and EPS* $\mathrm{S}_{\text {assets }}$ are correlated at a significant level of $1 \%$. The above results indicate a strong relationship between those variables, confirming the impact to firm's profitability.

Finally, in Table 3 regression results, for three subperiods, are presenting. The BV is $0.549,0.804$ and 0.773 (significant at $5 \%$ for the first two testing periods and at $1 \%$ for the third testing periods. Those results are confirm previous research for Greek market, which are report significant association between BV and Price levels (Athianos et al., 2005). These results for BV indicates that there is downward valuation for the period before mandatory adoption of IFRS.
In addition, EPS is positively associated with stock prices (significant at 1\%) for all testing periods. EPS coefficient magnitude also raised (8.209, 8.914 and 9.764, respectively for testing periods).

This positive growth for EPS as valuation variable, indicates a caution by the adoption of IFRS's.

Moreover, estimations for EPS* $S_{\text {goods }}$ coefficient are consistent with $\mathrm{H} 1$, since the results are -2.089 , 3.105 and 3.334 , significant at $10 \%$ for the first two periods and $5 \%$ for the last period. The negative coefficient for 2002-2004 period, indicate lower earnings for firms made inter-company transactions than the firms that not participate in these kinds of transactions. Significance levels also, suggest that the market discount the reported earnings prior and after the adoption, but in different level of significance.

The results for EPS* $S_{\text {assets }}$ coefficient are close to EPS*S goods coefficient. More specific, coefficient results are consistent with $\mathrm{H} 2$, since the results are2.345, 2.873 and 3.037, significant at 10\%. Comparing those two coefficients results, we can conclude that investors pay more attention to inter-company transactions, discounted the earnings in higher level, in case of selling assets rather than goods. 
Am. J. Applied Sci., 8 (2): 156-163, 2011

Table 3: Regression results

\begin{tabular}{|c|c|c|}
\hline Variables & Prediction & Coefficient \\
\hline \multicolumn{3}{|l|}{ Test period } \\
\hline \multicolumn{3}{|l|}{ 2002-2004 } \\
\hline Intercept & $\mathrm{n} / \mathrm{a}$ & $9.781^{* * *}$ \\
\hline BV & + & $0.549 * *$ \\
\hline EPS & + & $8.209 * * *$ \\
\hline EPS $^{*} \mathrm{~S}_{\text {goods }}$ & - & $-2.089 *$ \\
\hline $\mathrm{EPS}^{*} \mathrm{~S}_{\text {assets }}$ & - & $-2.345^{*}$ \\
\hline Adj $R^{2}$ & & 0.571 \\
\hline F-statistics & & $11.966^{* * *}$ \\
\hline \multicolumn{3}{|l|}{ 2004-2005 } \\
\hline Intercept & $\mathrm{n} / \mathrm{a}$ & $10.364 * * *$ \\
\hline BV & + & $0.804 * *$ \\
\hline EPS & + & $8.914 * * *$ \\
\hline EPS $^{*} S_{\text {goods }}$ & + & $3.105^{*}$ \\
\hline $\mathrm{EPS}^{*} \mathrm{~S}_{\text {assets }}$ & + & $2.873^{*}$ \\
\hline Adj $R^{2}$ & & 0.538 \\
\hline F-statistics & & $11.485^{* * *}$ \\
\hline \multicolumn{3}{|l|}{ 2005-2007 } \\
\hline Intercept & $\mathrm{n} / \mathrm{a}$ & $11.419 * * *$ \\
\hline BV & + & $0.773 * * *$ \\
\hline EPS & + & $9.764 * * *$ \\
\hline EPS $^{*} S_{\text {goods }}$ & + & $3.334^{* *}$ \\
\hline EPS* $S_{\text {assets }}$ & + & $3.037 *$ \\
\hline Adj $R^{2}$ & & 0.712 \\
\hline F-statistics & & $28.241^{* * *}$ \\
\hline
\end{tabular}

\section{CONCLUSION}

In this study we examine whether the disclosure of information about inter-company transactions contains value relevant information to investors Greece. Our testing period span from 2002-2007 separated into three sub testing periods, the period prior to adoption of IFRS's (2002-2004), period to change the accounting principles and rules (2004-2005) and a period after the adoption (2005-2007). Our results indicate that, investors discount earnings when valuing firms that engaged in inter-company (related party) sales transactions, concerning sales of goods and other assets.

During the period prior to adoption we observe that investors take account the effect of inter-company transactions (selling goods-EPS* $S_{\text {goods }}$ ) discounted the level of earnings and the value of the firm, but in a lower level of significant in comparison to the testing period after the adoption (10\% significant to $5 \%$ ). Also the level of magnitude to earnings is significant.

In addition, investors also discount the level of earnings due to inter-company transactions in assets $\left(E P S * S_{\text {assets }}\right)$ in a stable level of significance, prior and after the adoption of new accounting standards.

Concluding, our empirical results suggest that investors take more seriously account an inter-company transaction related to assets rather than goods, discounted in higher degree the earnings parameter.

Those results added value to new regulations, increasing the effectiveness of investors to reducing earnings manipulation by managers.

\section{REFERENCES}

Athianos, S., A. Vazakides and P. Arsenos, 2007. The accounting harmonization after the adoption of IAS's/IFRS's. The case of Greek listed companies. International Review of Applied Economic Research. http://dse.teiion.gr/Downloads/cvs/arsenos_gr.pdf

Athianos, S., A. Vazakidis and N. Dritsakis, 2005. Financial statement effects of adopting international accounting standards: The case of Greece. University of Macedonia. http://web.xrh.unipi.gr/hfaa/files/A21.pdf

Bae, K.H., J.K. Kang and J.M. Kim, 2002. Tunneling or value added? Evidence from mergers by Korean business groups. J. Finance, 57: 2695-2740. DOI: $10.1111 / 1540-6261.00510$

Baek, J.S., J.K. Kang and I. Lee, 2006. Business groups and tunneling: Evidence from private securities offerings by Korean chaebols. J. Finance, 61: 2415-2449. DOI: $10.1111 / \mathrm{j} .1540-$ 6261.2006.01062.x

Baek, J.S., J.K. Kang and K.S. Park, 2004. Corporate governance and firm value: Evidence from the Korean financial crisis. J. Financial Econ., 71: 265-313. DOI: 10.1016/S0304-405x(03)00167-3

Barth, M., W. Landsman and M. Lang, 2005. International accounting standards and accounting quality. Social Science Research Network, DOI: 10.2139/ssrn.688041

Barth, M.E., W.H. Beaver and W.R. Landsman, 2001. The relevance of the value relevance literature for financial accounting standard setting: Another view. J. Accoun. Econ., 31: 77-104. DOI: 10.1016/S0165-4101(01)00019-2

Beaver, W.H., 2002. Perspectives on recent capital market research. Accoun. Rev., 77: 453-474. DOI: 10.2308/ACCR.2002.77.2.453

Berkman, H., R.A. Cole and L.J. Fu, 2008. Expropriation through loan guarantees to related parties: Evidence from China. J. Bank. Finance, 33: 141-156. DOI: 10.1016/J.JBANKFIN.2007.11.001

Bertrand, M., P. Mehta and S. Mullainathan, 2002. Ferreting out tunneling: An application to Indian business groups. Q. J. Econ., 117: 121-148. DOI: 10.1162/003355302753399463 
Botosan, C. and M. Plumlee, 2002. A re-examination of disclosure level and the expected cost of equity capital. J. Accoun. Res., 40: 21-40. DOI: 10.1111/1475-679X.00037

Brockman, P. and D.Y. Chung, 2003. Investor protection and firm liquidity. J. Finance, 58: 921-938. DOI: 10.1111/1540-6261.00551

Bushman, R.M. and A.J. Smith, 2001. Financial accounting information and corporate governance. J. Accoun. Econ., 32: 237-333. DOI: 10.1016/S0165-4101(01)00027-1

Cheung, Y.L., P.R. Rau and A. Stouraitis, 2006. Tunneling, propping, and expropriation: Evidence from connected party transactions in Hong Kong. J. Finan. Econ., 82: 343-386. DOI: 10.1016/J.JFINECO.2004.08.012

Claessens, S., S. Djankov and L.H.P. Lang, 2000. The separation of ownership and control in East Asian corporations. J. Finan. Econ., 58: 81-112. DOI: 10.1016/S0304-405x(00)00067-2

Claessens, S., S. Djankov, J.P.H. Fan and L.H.P. Lang, 2002. Disentangling the incentive and entrenchment effects of large shareholdings. J. Finance, 57: 2741-2771. DOI: 10.1111/15406261.00511

Djankov, S., R.L. Porta, F. Lopez-de-Silanes and A. Shleifer, 2008. The law and economics of self-dealing. J. Finan. Econ., 88: 430-465. DOI: 10.1016/J.JFINECO.2007.02.007

Faccio, M., L.H.P. Lang and L. Young, 2001. Dividends and expropriation. Am. Econ. Rev., 91: 54-78. DOI: 10.1257/AER.91.1.54

Friedman, E., S. Johnson and T. Mitton, 2003. Propping and tunneling. J. Comparative Econ., 31: 732-750. DOI: 10.1016/J.JCE.2003.08.004

Gao, L. and G. Kling, 2008. Corporate governance and tunneling: Empirical evidence from China. PacificBasin Finance J., 16: 591-605. DOI: 10.1016/J.PACFIN.2007.09.001

Ge, W., D.H. Drury, S. Fortin, F. Liu and D. Tsang, 2010. Value relevance of disclosed related party transactions. Adv. Account., 26: 134-141. DOI: 10.1016/J.ADIAC.2010.02.004

Gordon, E., E. Henry, T. Lauwers and B. Reed, 2007. Auditing related party transactions: A literature overview and research synthesis. Account. Horizons, 21: 81-102. DOI: 10.2308/ACCH.2007.21.1.81

Gordon, E.A. and E. Henry, 2005. Related party transactions and earnings management. Social Science Research Network. http://papers.ssrn.com/sol3/papers.cfm?abstract_id $=612234$
Healy, P.M. and K.G. Palepu, 2001. Information asymmetry, corporate disclosure, and the capital markets: A review of the empirical disclosure literature. J. Account. Econ., 31: 405-440. DOI: 10.1016/S0165-4101(01)00018-0

Herrmann, D., T. Inoue and W.B. Thomas, 2003. The sale of assets to manage earnings in Japan. J. Accoun. Res., 41: 89-108. DOI: 10.1111/1475679X.00097

Iatridis, G. and S. Rouvolis, 2010. The post-adoption effects of the implementation of international financial reporting standards in Greece. J. Int. Accoun. Audit. Taxat, 19: 55-65. DOI: 10.1016/J.INTACCAUDTAX.2009.12.004

Jian, M. and T. Wong, 2008. Propping through related party transactions. Rev. Accoun. Stud., 15: 70-105. DOI: $10.1007 / \mathrm{s} 11142-008-9081-4$

Jian, M. and T.J. Wong, 2003. Earnings management and tunneling through related party transactions: Evidence from Chinese corporate groups. Social Science Research Network, DOI: 10.2139/ssrn.424888

Jian, M. and T.J. Wong, 2006. Propping through related party transactions. Rev. Account. Stu., 15: 70-105. DOI: $10.1007 / \mathrm{s} 11142-008-9081-4$

Jiang, G., C. Lee and H.v Yue, 2005. Tunnelling in China, The surprising pervasive use of corporate loans to extract funds from Chinese listed companies. Working paper, Johnson School Research Paper Series 31-06, Cornell University. http://www.baf.cuhk.edu.hk/research/cig/pdf_down load/JLY_060221_CUHK.pdf

Joh, S.W., 2003. Corporate governance and firm profitability: Evidence from Korea before the economic crisis. J. Finan. Econ., 68: 287-322. DOI: 10.1016/S0304-405x(03)00068-0

Johnson, S., 2000. Tunneling. Am. Econ. Rev., 90: 2227. DOI: $10.1257 / A E R .90 .2 .22$

Kohlbeck, M. and W.B. Mayhew, 2010. Valuation of firms that disclose related party transactions. J. Accoun. Public Policy, 29: 115-137. DOI: 10.1016/J.JACCPUBPOL.2009.10.006

La Porta, R., F. Lopez-de-Silanes and A. Shleifer, 1999. Corporate ownership around the world. J. Finance, 54: 471-517. DOI: 10.1111/0022-1082.00115

La Porta, R., F. Lopez-de-Silanes and A. Shleifer, 2006. What works in securities laws? J. Finance, 61: 1-32. DOI: 10.1111/J.1540-6261.2006.00828.X

La Porta, R., F. Lopez-de-Silanes and G. Zamarripa, 2003. Related lending. Q. J. Econ., 119: 231-268. DOI: $10.1162 / 00335530360535199$

La Porta, R., F. Lopez-de-Silanes, A. Shleifer and R. Vishny, 2000b. Investor protection and corporate governance. J. Finan. Econ., 58: 3-27. DOI: 10.1016/S0304-405x(00)00065-9 
La Porta, R., F. Lopez-de-Silanes, A. Shleifer and R. Vishny, 2002. Investor protection and corporate valuation. J. Finance, 57: 1147-1170. DOI: 10.1111/1540-6261.00457

La Porta, R., F. Lopez-de-Silanes, A. Shleifer and R.W. Vishny, 1998. Law and finance. J. Political Econ., 106: $1113-1155$. DOI: $10.1086 / 250042$

La Porta, R., F. Lopez-de-Silanes, A. Shleifer and R.W. Vishny, 2000a. Agency problems and dividend policies around the world. J. Finance, 55: 1-33. DOI: 10.1111/0022-1082.00199

Lemmon, L., L. Michael and V. Karl, 2003. Ownership structure, corporate governance, and firm value: Evidence from the East Asian financial crisis. J. Finance, 58: 1445-1468. DOI: 10.1111/15406261.00573

Leuz, C., 2003. IAS versus U.S. GAAP: Information asymmetry-based evidence from Germany's new market. J. Accoun. Res., 41: 445-472. DOI: 10.1111/J.1475-679x.2003.00111.X

Mandilas, A., S. Athianos, A. Tsamis and S. Aslani, 2004. The Greek accounting and tax framework. Main factors of influence. Proceedings of the 2nd International Conference on Accounting and Finance in Transition, July 9-11, Kavala, pp: 329-355.

Render, A. and A. Gaeremynck, 2007. The impact of legal and voluntary investor protection on the early adoption of International Financial Reporting Standards (IFRS). Economist, 155: 49-72. DOI: 10.1007/S10645-006-9041-Y
Sherman, H.D. and S. Young, 2001. Tread lightly through these accounting minefields. Harvard Bus. Rev., 79: 129-135. PMID: 11447613

Tarca, A., 2004. International convergence of accounting practices: Choosing between IAS and U.S. GAAP. J. Int. Finan. Manage. Accoun., 15: 60-91. DOI: 10.1111/J.1467-646x.2004.00102.X

Tendeloo, B. and A. Vanstraelen, 2005. Earnings management under German GAAP versus IFRS. Eur. Accoun. Rev., 14: 155-180. DOI: 10.1080/0963818042000338988

Vazakidis, A. and S. Athianos, 2010. Measuring investors' reaction to the adoption of international financial reporting standards in Greece, using a market-based model. Am. J. Econ. Bus. Admin., 2: 103-112. DOI: 10.3844/ajebasp.2010.103.112

Vazakidis, A., S. Athianos and E.C. Laskaridou, 2010. The importance of information through accounting practice in agricultural sector-european data network. J. Soc. Sci., 6: 221-228. DOI: 10.3844/jssp.2010.221.228

Weil, D., A. Fung, M. Graham and E. Fagotto, 2006. Regulation by transparency: The effectiveness of government mandated disclosure policies. J. Policy Anal. Manage., 25: 155-181. DOI: 10.1002/PAM.20160

Zarzeski, M., 1996. Spontaneous harmonization effects of culture and market forces on accounting disclosure practices. Accoun. Horizons, 10: 18-37. 